\title{
Investment for Development
}

\author{
Jeremy Clegg, University of Leeds, UK
}

Ram Mudambi, Temple University, USA

FOR OVER TWENTY YEARS, BEGINNING WITH the first World Investment Report (WIR) in 1991, the United Nations Conference on Trade and Development (UNCTAD) has presented international business scholars with the best and most comprehensive compilation of secondary data in the field. Initially, it focused predominantly on foreign direct investment (FDI) and economic activities of multinational enterprises (MNEs) based in advanced market economies. UNCTAD's overarching objective has always been on the link between international investment activity and economic development, broadly defined. However, the WIR moved with the times and has often been at the forefront of tracking the latest and most important economic and business trends in the global economy. These include topics like the rise of emerging economies, agriculture in the poorest economies, the role of infrastructure, a low-carbon economy to, most recently, sustainable development goals.

Till recently, UNCTAD carried this load mainly with its professional staff, supported by ad hoc groups of academics, initially led by John Dunning (Reading and Rutgers) and more recently by Peter Buckley (Leeds). Over the last year, UNCTAD has been pro-active and taken the lead in setting up a permanent collaborative research network, tentatively named the Global Academic Policy Research Network on Investment for Development. This network held its first gathering under the umbrella of the World Investment Forum (WIF) 2014 meetings held at UNCTAD's headquarters in the Palais de Nations, Geneva.

\section{The Objectives of the Research Network}

The international literature has documented the dramatic and extensive transformations in the operations of multinational enterprises over the last few decades. These include a wide variety of changes including subsidiary evolution towards increasing competence-creation (Birkinshaw and Hood, 1998; Cantwell and Mudambi, 2005), a rapid migration of value creation to knowledge-based intangibles (Mudambi, 2008), the rise to prominence (and even preeminence in some cases) of FDI from large, vibrant emerging markets (Buckley, et al., 2007) as well as MNEs from emerging markets (Awate, et al., 2012; 2015) and the increasing importance of incorporating sustainability and base of the pyramid logics into international competitive strategies (London and Hart, 2004).
The extent and speed at which the global economy is evolving continues to increase with both a faster pace of the cycle of innovation (Mudambi and Swift, 2014) as well as the active entry of ever more decision-makers (such as sovereign wealth funds, private equity funds and state-owned enterprises (SOEs)) into the global business arena (Gilson and Milhaupt, 2007; Cumming and Walz, 2010; Wang et al., 2012). Simultaneously, the international community is confronted with a set of problems whose scale and complexity is unprecedented. In this environment, it is critical for policy makers to take a long view and develop holistic approaches.

In describing its vision for the research network UNCTAD notes that it will require "that investment is reconfigured to better harness the contribution of MNEs for development, especially in light of the contemporary MNE universe and the new balance between the public and private sectors". In the coming years, investment must confront formidable challenges that include climate change, declining biodiversity, increasing gaps between rich and poor as well as the under and unemployment of millions that represents an intolerable waste of human potential. These challenges represent threats to our very existence and "finding solutions requires the engagement of all investment stakeholders, especially cutting-edge academic research that can shine the light for sustainable alternatives going forward." 


\section{Meeting at the World Investment Forum, Octo ber 15, 2014}

The first meeting of the Research Network was held on 15th October 2014, in the form of a multidisciplinary academic conference. It was arranged during the WIF in partnership with the Geneva Graduate Institute, the Academy of International Business (AIB), the Society of International Economy and Law (SIEL), and the European International Business Academy (EIBA). The theoretical outline for the research agenda was discussed in a wide-ranging Roundtable. The detailed ideation was organized around six thematic research areas, each facilitated by academic thought leaders selected from amongst UNCTAD advisors. These were: Opportunities and Challenges; Systemic Issues and Institutions; Development and Investment Strategies; Responsibility and Sustainability; Investment Impact; Coherence and Synergies.

\section{Roundtable}

The objective of the Roundtable was to develop a holistic view of the development process whilst retaining theoretical rigor. It was based on two fundamental insights: (a) the central role of innovation in modern value creation and (b) key role of connectivity in both enabling innovation as well as bringing marginal geographical locations into the global economic system. This discussion was based on the International Business, Economic Geography and Innovation (iBEGIN) research program anchored at several institutions, including Temple University (USA), Copenhagen Business School (Denmark), Politecnico di Milano (Italy) and Indian School of Business (India) among others.

At the Geneva meeting, the iBEGIN research agenda was discussed in a Roundtable and lead by Peter Buckley (Leeds), Mario Brincat (Malta Enterprise), L. Felipe Monteiro (INSEAD), Ram Mudambi (Temple), Miguel Torres (Aveiro), and moderated by Jeremy Clegg (Leeds). Buckley discussed the Global Factory model as an operationalization of (international) connectivity (Buckley, 2009). Maro Brincat (Malta Enterprise) highlighted the role of inward investment by MNEs are a potential source of rapid local development and discussed the recent policy initiatives of Malta Enterprise. L. Felipe Monteiro (INSEAD) discussed the role of MNE subsidiaries in local development, focusing particularly on the Chinese context. Ram Mudambi (Temple) presented comparative longitudinal analysis of Korea and Brazil (Hannigan et al., 2013). This study concludes that connectivity to the global economy is one of the main reasons for the Korea's rapid ascension to the ranks of the world's rich countries (it was admitted to the OECD in 1996). In contrast, Brazil's more inward-oriented stance is one of the reasons that it is mired in the middle income trap. Miguel Torres (Aveiro) spoke on the growthsustainability trade-off. Jeremy Clegg (Leeds) moderated the lively discussion from participants and the audience.

\section{Areas for Research}

In this short review, we cannot do justice to the breadth and depth of comments and ideas put forward at the event, but we highlight the key conference outcomes under the thematic headings, and sketch out "research gaps related primarily to investment and development, with the aim of encouraging policy oriented research" - which was the overarching theme of the conference. The areas for research were discussed and developed in six"parallel talk" sessions comprising around 20 participants in each, drawn from academia. Not surprisingly, the live discussions naturally developed their own particular takes on the briefs initially handed to the session co-chairs, replete with 30-odd research questions per session. Here, we set out some avenues for International Business research in developing economies and emerging markets that flow from this first meeting of the Research Network.

\section{Research Area 1: Opportunities and Challenges}

The brief for this area centered on the rapidity of changes pervading the world economy, with an emphasis on the imperative to government action, business investors and academic thought to be agile enough to take cognizance and advantage of the opportunities created, while anticipating and mitigating the pitfalls that inevitably open up to confound the sustainable development agenda.

Big picture thinking is needed but, for this to be effective, a way of modelling the world is essential. The entry of emerging country investors, private equity and sovereign wealth funds, and state-owned multinational enterprises all represent considerable extensions or departures from the conventional advanced-economy model of outward international investment, the impacts of which are as yet only poorly understood. Applying tried and tested ways of analysis to new categories of investment seems potentially lucrative, but it is evident that this cannot be the preserve of any single field of study. For sustainable development, the economic impacts must be addressed alongside, for example, the social and the distributional. These aspects are reprised and treated in the other five research areas.

\section{Research Area 2: Systemic Issues and Institutions}

Institutional analysis has yielded a way of thinking and taking action that can be applied systemically, at different levels of governance - at the national, regional, bilateral, and multilateral. Here the challenge is to reconcile the conceptual elegance of systemic thinking with the reality of managing for the better. To achieve this demands access to accurate data with which to understand the true nature of current regimes. This is a sine qua non to appraise investor-state disputes, arbitral claims that have been settled, and the effects of adherence to new treaties on the rule of law in states. The growth of trade managed within global value chains (GVCs) naturally raises questions about the adequacy of provisions within investor-state treaties, and free trade agreements (FTAs). In fact, this is one of several nexuses into which the sessions (and indeed the Multidisciplinary Academic Conference overall) coalesced: the traction that institutions and policy actually exerts, and can exert, over real-world behaviors. Understanding these mechanisms is essential for the achievement of development that is sustainable. 


\section{Research Area 3: Development and Investment Strategies}

Actually mobilizing international investment to achieve sustainable and inclusive development-growth that benefits, all including the poorest-was at the heart of the conference. Discussions in this research area focused on, again, global value chains - which have transformed not only the way we think about the international economy, but also the way in which the international economy behavesand how, through enlightened policy governments can effectively promote national development agendas. The leeway that is available to countries to optimize their participation in GVCs - in this context meaning to optimize for sustainable development-was an area identified for particular research focus. Trade-offs are inevitable between objectives that are desirable, but recognizing and targeting goals such as social cohesion, are part of the new agenda for sustainability, and go far beyond the notion of economic growth at all costs.

\section{Research Area 4: Responsibility and Sustainability}

It could not be more clear that the strategies for Research Area 4 have to embody systemically-congruent thinking for the social good, and that this thinking must, somehow, be not only present in economic actors pursuing their business goals, but must also be promoted by them in the form of investment. Embedding responsibility and sustainability in, for example for-profit private sector firms (though it applies no less to the other actors noted here, e.g., SOEs) is the mainspring of this particular research area. The term "corporate social responsibility" is well known, and well used to mean the extensification of social value creation (or, at least, not destruction). Investment that is pro-greenhouse gas emissions reduction, promotes food, water and energy security in the development process, is concrete exemplification of responsible and sustainable behavior. But there may be a fine line between such exemplary behavior and the regular business-as-usual activities of multinational firms - for instance, in certain infrastructural investments - or firms that market products in developing economies that by their nature, may have deleterious effects on public health. The nature of the impact, rather than the category of the investment, is what really counts for the social good.

\section{Research Area 5: Investment Impact}

Investment impact is now recognized to be a two-way street. It has long been recognized that inward investment is a valuable development tool. But it is a relatively new phenomenon that outward investment is seen as a home-country development tool in its own right, indeed, it is not so very long ago that outward investment was viewed with suspicion as a form of capital flight. For impact to be of value, it is necessary that it is sustained. By its nature, foreign direct investment (FDI) tends to be long term, and to have long term impacts, although the session posed the question of how these investments could be made yet more "sticky" and long-lasting. Direct and indirect employment, technology transfer and diffusion, competition effects and demonstration effects are the conventional categories of investment impact-and they may well benefit developing economies as outward investors, as well as in their role as host countries. And they may also be beneficial for some aspects of sustainable development. But, there are new types of impact to which the sustainable development agenda has drawn our collective attention, such as the potential for beneficial gender-specific and pro-inclusion (of marginalized or excluded groups) impacts-again outward FDI from developing economies may help here.

\section{Research Area 6: Coherence and Synergies}

Not to recognize these many different dimensions to sustainability is not to see the coherence that must be sought-between national and international investment policies, and between investment and other policies which impinge upon the capacity to achieve sustainable development. Trade, taxation, the environment, human rights and social policies all need to be aligned, so that when sustainable development is professed it is not undermined by weakness in any other single aspect of policy. In the trade and investment policy sphere, discussion in this session ranged over policies and standards, and the content of future international investment agreements (IIAs). Making the link between legal text and the actual behavior of firms (but not only firms) is a task for academic researchers in particular, as policymakers know remarkably little about how responsive to policy incentives are the primary agents of sustainable impact. The discussion noted that while there has been an extensive body of earlier work on how to improve the conduct of treaty negotiations, the main work for the future is to cultivate research on how to make provisions more effective. Only if they are effective can policies for sustainable development have a hope of achieving their goals.

It is evident that, for all the analysis that can be conducted, the sustainable development agenda is one that confronts us to ask the question of whether the lives of people are bettered, and bettered in a manner that is sustainable for as long as we can see. To be coherent this must bring in the natural environment, for everybody depends ultimately on this. To benefit from synergies we have to recognize that each of the research areas identified depend, for their value, on each other.

\section{Avenues for International Business Research in Developing Economies}

It is clear that multidisciplinary research is necessary to meet the sustainable development agenda. A perfect example of this is the need to understand how book law (including incentives) is actually taken up in the form of actions by firms, as it is only through the actions of principal actors that the sustainable development agenda can be realized. But it does not end there, the social aspects of development, not least social cohesion, are fundamental to sustainability, as are the environmental, to name but a few. And while the existence of trade offs complicates the need for research, it does not negate it. Such a complication is the rise of trade within GVCs which, it is believed, has changed 
the scope that conventional policy thinking has for effecting development policy outcomes. Research is needed to investigate exactly how has it changed, and what this means for the developing economies' prospects of sustainable development.

Corporate philanthropy, by firms that have profit objectives, may be an important component for achieving sustainable development, especially in a world where governments are relatively impecunious. But in what circumstances is it a good thing overall, and when is it not? This is an altogether more complex world for research. And specific non-traditional impacts of international investment demand further study, going beyond distributional effects to include questions of equity between the different natural groupings of people, for instance by gender, by ethnicity and culture within populations, and by disability. International investment has the potential, in certain circumstances, to be emancipatory, as MNEs can be the first to bring in higher standards of workforce treatment to developing economies. And finally, how to convert aspiration into action, requires technical research under the heading of coherence and synergies, and a connected approach to evaluating the consequences of policy actions in one sphere for the others.

\section{Going Forward}

The first meeting of the Research Network in Geneva developed the outlines of an ambitious research agenda that was further explicated at a panel session at the European International Business Academy meetings in Uppsala in early December, 2014. Going forward, UNCTAD's intention is to build on this momentum in terms of the research agenda and academic network, by expanding the network beyond international business, development economics and law to encompass other fields of relevance to investment for development. The network seeks the support of other associations, as well as the active participation of colleagues in areas potentially as diverse as organizational theory, political economy and economic geography.

\section{References}

Awate, S., Larsen, M.M., and Mudambi, R. 2012. EMNE catch-up strategies in the wind turbine industry: Is there a trade-off between output and innovation capabilities? Global Strategy Journal, 2(3): 205-223.

Awate, S., Larsen, M.M., and Mudambi, R. 2015. Accessing vs. sourcing knowledge: A comparative study of R\&D internationalization between emerging and advanced economy firms. Journal of International Business Studies, 46(1): 63-86.

Birkinshaw, J. and Hood, N. 1998. Multinational subsidiary evolution: Capability and charter change in foreign-owned subsidiary companies. Academy of Management Review, 23(4): 773-795.
Buckley, P., Clegg, J., Cross, A., Liu, X., Voss, H., and Zheng, P. 2007. The determinants of Chinese outward FDI. Journal of International Business Studies, 38: 499-518.

Buckley, P. 2009. The impact of the global factory on economic development. Journal of World Business, 44(2): 131-143.

Cantwell, J. and Mudambi, R. 2005. MNE competence-creating subsidiary mandates. Strategic Management Journal, 26(12): 1109-1128.

Cumming, D. and Walz, U. 2010. Private equity returns and disclosure around the world. Journal of International Business Studies, 41: 727-754.

Gilson, R. and Milhaupt, C. 2007. Sovereign wealth funds and corporate governance: A minimalist response to the new mercantilism. Stanford Law Review, 60: 1345-1368.

Hannigan, T.J., Lee, A. and Mudambi, R. 2013. The pitfalls of an inwardoriented economy: Lessons from the evolution of Brazil and the Republic of Korea. Transnational Corporations, 22(2): 1-24.

London, T. and Hart, S. 2004. Reinventing strategies for emerging markets: Beyond the transnational model. Journal of International Business Studies, 35: 350-370.

Mudambi, R. 2008. Location control and innovation in knowledge-instensive industries. Journal of Economic Geography, 8(5):6990725.

Mudambi, R. and Swift, T. 2014. Knowing when to leap: Transitioning between exploitative and explorative R\&D. Strategic Management Journal, 35(1): 126-145.

Wang, C., Hong, J., Kafouros, M. and Wright, M. 2012. Exploring the role of government involvement in outward FDI from emerging economies. Journal of International Business Studies, 43: 655-676.

Jeremy Clegg (ljc@lubs.leeds.ac.uk) is Jean Monnet Professor of European Integration and International Business Management, and Director of the Centre for International Business University of Leeds (CIBUL). In 2007 he received the AIB President's (now John H. Dunning) Award for his work as chair of the UK \& Ireland Chapter of the Academy, and in 2008-09 he was a visiting fellow at UNCTAD. His research has been published in all of the major International business journals.

Ram Mudambi (RMudambi@temple.edu) is the Frank M. Speakman Professor of Strategy and Perelman Senior Research Fellow at the Fox School of Business, Temple University. He is an AIB Fellow, has served as an Associate Editor of GSJ (2010-2013) and is an Area Editor at JIBS (2013-2016). His work has appeared in Journal of Political Economy, Journal of Economic Geography, SMJ and JIBS, among others. He serves on the editorial boards of numerous journals. 